\title{
Overcoming paclitaxel resistance in uterine endometrial cancer using a COX-2 inhibitor
}

\author{
KIYOSHI HASEGAWA ${ }^{1}$, KUNIMI ISHIKAWA ${ }^{2}$, SATOSHI KAWAI ${ }^{3}$, YUTAKA TORII ${ }^{3}$, \\ KYOKO KAWAMURA $^{3}$, RINA KATO ${ }^{3}$, KAZUHIKO TSUKADA ${ }^{1}$ and YASUHIRO UDAGAWA ${ }^{3}$ \\ ${ }^{1}$ Department of Obstetrics and Gynecology, Fujita Health University, Banbuntane Hotokukai Hospital, Nagoya, \\ Aichi 454-8509; ${ }^{2}$ Kaseki Hospital, Nagoya, Aichi 460-0008; ${ }^{3}$ Department of Obstetrics and Gynecology, \\ Fujita Health University School of Medicine, Nagoya, Aichi 454-8509, Japan
}

Received July 22, 2013; Accepted September 9, 2013

DOI: $10.3892 / o r .2013 .2790$

\begin{abstract}
Cyclooxygenase (COX)-2 inhibitors have been reported to potentially modulate the resistance of cancer cells to chemotherapeutic drugs by affecting multidrug resistance 1 (MDR1) expression. In the present study, we investigated the association between COX-2 and MDR1 expression in endometrial cancers and evaluated the effects of the COX-2 inhibitor, etodolac, in combination with paclitaxel on paclitaxel-resistant endometrial cancer cells. The relationship between $\mathrm{COX}-2$ and MDR $1 \mathrm{mRNA}$ expression was examined by quantitative PCR in 36 endometrial cancer specimens. The paclitaxelresistant cell line OMC-2P was established from OMC-2 cells. Paclitaxel $(1 \mu \mathrm{g} / \mathrm{ml})$ with or without etodolac $(10 \mu \mathrm{g} / \mathrm{ml})$ was added to OMC-2 and OMC-2P cells, and COX-2 and MDRI mRNA expression levels were examined. The concentration of prostaglandin $\mathrm{E}_{2}\left(\mathrm{PGE}_{2}\right)$ in the supernatant of each cell line was examined by enzyme-linked immunosorbent assay. The function of MDR1 was determined by intracellular accumulation of Rhodamine 123 using flow cytometry, and the concentration of intracellular paclitaxel was determined by high-performance liquid chromatography. We found a positive relationship between $C O X-2$ and $M D R 1$ mRNA expression in endometrial cancer. Both $C O X-2$ mRNA expression and $\mathrm{PGE}_{2}$ production were elevated in resistant OMC-2P cells when compared to non-resistant OMC-2 cells. Additionally, $M D R 1$ mRNA expression was markedly upregulated in OMC-2P cells. In OMC- 2 cells, $C O X-2$ and MDR 1 mRNA levels were significantly upregulated by paclitaxel treatment and downregulated by co-administration with etodolac. In OMC-2P cells, COX-2 mRNA expression was also significantly upregulated by paclitaxel treatment and tended to be
\end{abstract}

Correspondence to: Dr Kiyoshi Hasegawa, Department of Obstetrics and Gynecology, Fujita Health University, Banbuntane Hotokukai Hospital, 3-6-10 Otobashi, Nakagawa-ku, Nagoya, Aichi 454-8509, Japan

E-mail: khase@fujita-hu.ac.jp

Key words: endometrial cancer, COX-2, COX-2 inhibitor, paclitaxel resistance, MDR1 downregulated by co-administration with etodolac. Moreover, co-administration of paclitaxel and etodolac suppressed the induction of MDRl mRNA. Rhodamine 123 efflux was increased in OMC-2P cells when compared to the efflux in the OMC-2 cells and was increased in response to paclitaxel treatment. Co-administration of paclitaxel and etodolac in both cell lines resulted in decreased Rhodamine 123 efflux. The actual concentration of intracellular paclitaxel in OMC-2P cells was significantly lower than that in OMC-2 cells treated with paclitaxel alone and was significantly increased after co-administration of paclitaxel and etodolac. These findings suggest that paclitaxel resistance may be associated with COX-2 and MDR1 expression in cancer cells. Co-administration of COX-2 inhibitors and paclitaxel may have a key role in modulating or overcoming paclitaxel resistance in endometrial cancers.

\section{Introduction}

Recent studies have identified a role for cyclooxygenase- 2 (COX-2) in the development and progression of various tumor types. In vitro and in vivo investigations have shown that selective COX-2 inhibitors produce antiproliferative effects in various malignancies, such as gastric, esophageal, oral, brain, lung and pancreatic cancers (1). Several studies have demonstrated the antitumor effects of selective COX-2 inhibitors on endometrial cancer in vitro (2-4). Moreover, small pilot studies have described the effects of oral administration of selective COX-2 inhibitors in prostate cancer and endometrial cancer patients $(5,6)$. In a previous study, we found that the selective COX-2 inhibitor etodolac showed antiproliferative effects by suppressing COX-2 and cell-cycle regulator protein expression in patients with endometrial cancer positive for $\mathrm{COX}-2$ expression (6).

In addition to the use of COX-2 inhibitors alone, co-administration of chemotherapeutic agents with selective COX-2 inhibitors has been shown to enhance the effects of the chemotherapeutic agent in pancreas and lung cancer cell lines and animal models (6-8), and several clinical trials using selective COX-2 inhibitors have been conducted for human cancers. In phase II clinical trials for non-small cell lung cancer, the COX-2 inhibitor celecoxib was shown to 
significantly enhance the response to conventional chemotherapeutic agents, i.e., carboplatin and paclitaxel (9). Similar phase II studies of selective COX-2 inhibitors in combination with chemotherapeutic drugs with good efficacy and safety have been reported in patients with pancreatic (10) and small cell lung cancer (11).

Moreover, the association between COX-2 expression and multidrug resistance 1 (MDR1) expression has been reported in various types of cancers (12-15). Drug resistance may involve the $M D R 1$ gene, which encodes the transmembrane glycoprotein p-170 (P-gp). P-gp is a transmembrane phosphoglycoprotein from the ATP-binding cassette superfamily (ABC) and functions as an efflux pump, transporting a wide range of compounds and, therefore, facilitating decreased intracellular drug concentrations and reduced cancer chemotherapy efficacies of such drugs as doxorubicin $(16,17)$ and paclitaxel (18). COX-2 inhibitors have been reported to potentially modulate resistance to chemotherapeutic drugs by affecting MDR1 expression and enhancing the effects of conventional chemotherapeutic agents $(12-15,19,20)$. Ratnasinghe et al (12) proposed that COX-2 inhibitors may act as chemosensitizers, improving the efficacy of chemotherapeutic agents in part by inhibiting MDR1.

In ovarian cancer, COX-2 and MDR1 expression levels are associated with chemotherapy resistance and poor prognosis $(21,22)$. Therefore, the combination of a selective COX-2 inhibitor and a chemotherapeutic drug may enhance the effects of the chemotherapeutic drug alone.

However, no studies have investigated the relationship between COX-2 and MDR1 expression in endometrial cancer. Therefore, in the present study, we investigated the association between $C O X-2$ and MDR 1 mRNA expression in endometrial cancers and evaluated the effects of the COX-2 inhibitor etodolac in combination with paclitaxel on paclitaxel-resistant endometrial cancer cells. We also investigated the possibility of overcoming paclitaxel resistance by modulation of MDR1 expression and activity.

\section{Materials and methods}

Relationship between COX-2 and MDR1 mRNA expression. Thirty-six patients with pathologically confirmed endometrial carcinoma who underwent surgery at our institution from 2004 to 2008 were enrolled in the present study after providing informed consent. Thirty-six surgical specimens were subjected to real-time quantitative RT-PCR to confirm the expression levels of $C O X-2$ and MDRI mRNA, and the relationship between these transcripts was examined. Pathologically confirmed histological subtypes included endometrioid adenocarcinoma $(n=25)$, serous adenocarcinoma $(n=5)$ and clear cell adenocarcinoma $(n=6)$. Total RNA was extracted from tumor samples using an RNeasy kit (Qiagen, Tübingen, Germany), following the manufacturer's instructions and was then subjected to complementary DNA (cDNA) synthesis using a High-Capacity cDNA reverse transcription kit (Applied Biosystems, Foster City, CA, USA). cDNA was subsequently used for fluorescence-based real-time quantitative RT-PCR (TaqMan PCR) with an ABI Prism 7900 Sequence Detector System (Applied Biosystems) according to methods described elsewhere $(23,24)$. The housekeeping gene glyceraldehyde 3-phosphate dehydrogenase (GAPDH) served as an internal control due to its stable expression in different tissues. Primers and TaqMan probes were purchased from Applied Biosystems, and the following primers were used: COX-2 forward, CCTTCCTCCTGTGCCTGATG and reverse, ACAATCTCATTTGAATCAGGAAGCT; MDR1 forward, GTGGTGTTTCAGAATGGCAGAGT and reverse, AGC CTGGACACTGACCATTGA; GAPDH forward, GAAGGT GAAGGTCGGAGTC and reverse, GAAGATGGTGATGG GATTTC.

TaqMan probes were labeled with the reporter dye 6-carboxyfluorescein (FAM) at the 5'-end of the oligonucleotide and with the quencher dye 6-carboxytetramethylrhodamine (TAMRA) at the 3'-end. The PCR conditions were as follows: $50^{\circ} \mathrm{C}$ for $2 \mathrm{~min}$ and $95^{\circ} \mathrm{C}$ for $10 \mathrm{~min}$, followed by 40 cycles at $95^{\circ} \mathrm{C}$ for $15 \mathrm{sec}$ and $60^{\circ} \mathrm{C}$ for $1 \mathrm{~min}$. All assays were run in triplicate. The data were analyzed by the $\Delta \Delta \mathrm{Ct}$ method for comparing relative expression results (ratio, $2-\left[C t_{\text {sample }}-\right.$ $\left.\left.C t_{G A P D H}\right]\right)$, where $\mathrm{Ct}$ means the threshold cycle. The relative quantity of mRNA was represented as the mean \pm standard deviation (SD).

Establishment of a paclitaxel-resistant endometrial cancer cell line. To establish a paclitaxel-resistant cell line, we used the uterine endometrial cancer cell line, OMC-2 (25), which was derived from a moderately differentiated tumor and has been shown to express COX-2 mRNA and protein. OMC- 2 cells were grown in Ham's F-12 medium supplemented with $10 \%$ fetal bovine serum (FBS), $100 \mathrm{U} / \mathrm{ml}$ penicillin and $100 \mu \mathrm{g} / \mathrm{ml}$ streptomycin at $37^{\circ} \mathrm{C}$ in a humidified $5 \% \mathrm{CO}_{2}$ atmosphere. A clone of paclitaxel-resistant OMC-2 cells was selected by incubating 'native' OMC-2 cells in the presence of paclitaxel from 0 to $1 \mu \mathrm{g} / \mathrm{ml}$, gradually escalating the dose of paclitaxel over a period of 4 months. The $\mathrm{IC}_{50}$ values for paclitaxel and doubling times in 'native' and 'resistant' OMC-2 cells were calculated by MTT assay and growth curves, respectively.

Analysis of COX-2 and MDR1 mRNA expression in endometrial cancer cells. OMC-2 and OMC-2P cells were seeded in $5-\mathrm{cm}$ dishes at $1 \times 10^{5}$ cells/well and were grown in medium containing $1 \mu \mathrm{g} / \mathrm{ml}$ paclitaxel alone, $10 \mu \mathrm{g} / \mathrm{ml}$ etodolac alone or $1 \mu \mathrm{g} / \mathrm{ml}$ paclitaxel plus $10 \mu \mathrm{g} / \mathrm{ml}$ etodolac for $24 \mathrm{~h}$. Total RNA from these cells was extracted using an RNeasy kit as previously described. Real-time RT-PCR was then used to analyze the expression of $C O X-2$ and $M D R 1$ mRNA as previously described.

Measurement of $P G E_{2}$ concentrations in the supernatants of endometrial cancer cells. OMC-2 and OMC-2P cells were seeded in 6-well dishes at $1 \times 10^{5}$ cells/well and were grown in medium containing $1 \mu \mathrm{g} / \mathrm{ml}$ paclitaxel alone, $10 \mu \mathrm{g} / \mathrm{ml}$ etodolac alone or $1 \mu \mathrm{g} / \mathrm{ml}$ paclitaxel plus $10 \mu \mathrm{g} / \mathrm{ml}$ etodolac for $24 \mathrm{~h}$. The concentration of prostaglandin $\mathrm{E}_{2}\left(\mathrm{PGE}_{2}\right)$ in the conditioned medium collected from each well was determined by enzyme-linked immunosorbent assay (ELISA) and was normalized to the total protein concentration. This experiment was run in triplicate.

Rhodamine 123 efflux assay. The function of MDR1 was determined by intracellular accumulation of Rhodamine 123 
(R123) using flow cytometry $(13,17)$. Subconfluent OMC-2 and $\mathrm{OMC}-2 \mathrm{P}$ cells were incubated in medium containing $1 \mu \mathrm{g} / \mathrm{ml}$ paclitaxel with or without $10 \mu \mathrm{g} / \mathrm{ml}$ etodolac at $37^{\circ} \mathrm{C}$ in a humidified $5 \% \mathrm{CO}_{2}$ atmosphere for $24 \mathrm{~h}$. The cells were then incubated in HEPES-buffered solution consisting of $125 \mathrm{mM}$ $\mathrm{NaCl}, 5 \mathrm{mM} \mathrm{KCl}, 1 \mathrm{mM} \mathrm{MgSO}$, $1.36 \mathrm{mM} \mathrm{Na}_{2} \mathrm{HPO}_{4}, 10 \mathrm{mM}$ sodium acetate, $5 \mathrm{mM}$ HEPES, $1.8 \mathrm{mM} \mathrm{CaCl}_{2}$, and $8 \mathrm{mM}$ glucose titrated to $\mathrm{pH} 7.4$ and treated with $1 \mu \mathrm{M} \mathrm{R} 123$ for $1 \mathrm{~h}$ at $37^{\circ} \mathrm{C}$. The cells were collected by incubation with trypsin containing phosphate-buffered solution with $1 \mu \mathrm{M}$ R123, washed 3 times with HEPES-buffered solution and centrifuged at $1,500 \mathrm{rpm}$ for $5 \mathrm{~min}$ at $4^{\circ} \mathrm{C}$. After the supernatant containing extracellular R123 was removed, loading was measured by flow cytometry using a FACSCalibur (Becton-Dickinson, Franklin Lakes, NJ, USA) to examine the initial level of intracellular accumulation of R123. Next, the cells were resuspended in HEPES-buffered solution and incubated for $2 \mathrm{~h}$ at $37^{\circ} \mathrm{C}$. After centrifugation at $1,500 \mathrm{rpm}$ for $5 \mathrm{~min}$ at $4^{\circ} \mathrm{C}$ to remove any extracellular R123, the level of R123 retained in the cells was measured by flow cytometry to determine the efflux of R123. The histogram of immunofluorescence of the cell population was plotted using CellQuest software (Becton-Dickinson). The lowest fluorescence intensity of the cells taking up R123 at initial loading was defined as M1, and the percentage of R123 effluxed cells to all cells including the M1 value was calculated. All experiments were carried out in triplicate.

Measurement of intracellular paclitaxel concentrations. Subconfluent OMC-2 and OMC-2P cells were incubated in medium containing $1 \mu \mathrm{g} / \mathrm{ml}$ paclitaxel with or without $10 \mu \mathrm{g} / \mathrm{ml}$ etodolac at $37^{\circ} \mathrm{C}$ in a humidified $5 \% \mathrm{CO}_{2}$ atmosphere for $6 \mathrm{~h}$. The cells were collected by incubation with trypsin in phosphate-buffered solution, washed 3 times with phosphatebuffered solution and centrifuged at 3,000 rpm for $5 \mathrm{~min}$ at $4^{\circ} \mathrm{C}$. The weight of the cell pellet was measured, and the pellet was homogenized by ultrasonication in ice-cold water after addition of $1 \mathrm{ml}$ of $0.07 \mathrm{M}$ phosphate buffer. After centrifugation at 3,000 rpm for $5 \mathrm{~min}$ at $4^{\circ} \mathrm{C}$, the supernatant was applied to HPLC (L-7100; Hitachi, Tokyo, Japan), following the manufacturer's instructions, in order to determine the concentration of paclitaxel.

Statistical analysis. The statistical analysis was performed using the Chi-square test or the Student's t-test. Differences with a P-value $<0.05$ were considered to indicate a statistically significant result.

\section{Results}

Relationship between COX-2 and MDR1 mRNA expression. There was a positive correlation between $C O X-2$ and $M D R I$ mRNA expression in the 36 endometrial carcinoma specimens ( $\mathrm{r}=0.560, \mathrm{P}=0.001$; Fig. 1). Moreover, $C O X-2$ and $M D R 1$ mRNAs were associated with type 2 non-endometrioid adenocarcinomas, such as serous or clear cell adenocarcinomas, as well as type 1 endometrioid adenocarcinomas (data not shown).

Characterization of paclitaxel-resistant endometrial cancer cells. The obtained paclitaxel-resistant cell line was designated

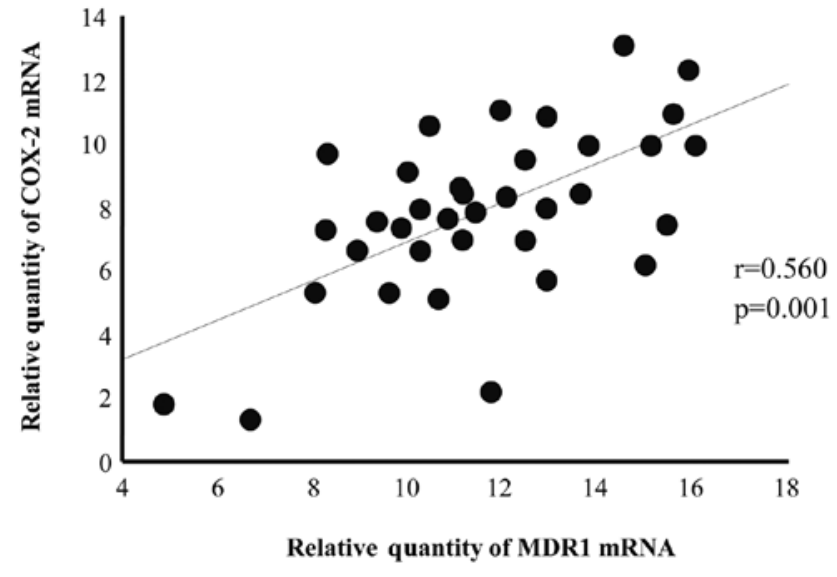

Figure 1. Relationship between COX-2 and MDR1 mRNA expression. There was a positive correlation between $C O X-2$ and $M D R 1$ mRNA expression in the 36 endometrial carcinoma specimens $(\mathrm{r}=0.560, \mathrm{P}=0.001)$.

as OMC-2P. The morphological appearances of the 'native' OMC-2 and 'resistant' OMC-2P cells were almost identical as determined by phase-contrast microscopy. $\mathrm{The} \mathrm{IC}_{50}$ values for paclitaxel (after 3 days of exposure) in OMC-2 and OMC-2P cells, as calculated by MTT assay, were 0.11 and $1.95 \mu \mathrm{g} / \mathrm{ml}$, respectively, demonstrating that $\mathrm{OMC}-2 \mathrm{P}$ cells were 17.7 times more resistant to paclitaxel than the parental cells (data not shown). The doubling times of OMC-2 and OMC-2P cells, calculated by growth curves, were 36 and 48 h, respectively (data not shown).

Analysis of COX-2 and MDR1 mRNA expression in endometrial cancer cell lines. When the relative quantity of $C O X-2$ mRNA in the control OMC-2 cells was defined as 1.0 , the expression levels were $9.10 \pm 0.89,0.77 \pm 0.18$ and $6.75 \pm 0.78$ in the OMC-2 cells treated with paclitaxel alone, etodolac alone, or co-administration of paclitaxel and etodolac, respectively. $C O X-2$ expression was significantly upregulated by paclitaxel treatment $(\mathrm{P}<0.01)$ compared to that of the untreated control and was downregulated by co-administration with etodolac when compared to that of cells treated with paclitaxel alone $(\mathrm{P}<0.05$; Fig. 2). In the OMC-2P cells, $C O X-2$ expression levels were $3.09 \pm 0.25,5.58 \pm 0.72,3.80 \pm 0.32$ and $4.50 \pm 0.36$ in the control, paclitaxel-treated, etodolac-treated, and paclitaxel plus etodolac-treated cells, respectively. $C O X-2$ mRNA expression was also significantly upregulated by paclitaxel treatment $(\mathrm{P}<0.01)$ when compared to that of the control and tended to be downregulated by co-administration with etodolac $(\mathrm{P}=0.067$; Fig. 2). The expression of $C O X-2$ in the control OMC-2P cells was about 3-times higher than that in the control OMC-2 cells.

When the relative quantity of MDRI mRNA in the control 'native' OMC-2 cells was defined as 1.0, the expression levels of MDR $1 \mathrm{mRNAs}$ were $2.90 \pm 0.48,1.56 \pm 0.30$ and $2.20 \pm 0.54$ in the OMC-2 cells treated with paclitaxel alone, etodolac alone, or both paclitaxel and etodolac, respectively. Additionally, $M D R 1$ expression was significantly upregulated by paclitaxel treatment $(\mathrm{P}<0.01)$ when compared to that of the control cells and was downregulated by co-administration of paclitaxel and etodolac when compared to that of cells treated with paclitaxel alone ( $\mathrm{P}<0.05$; Fig. 3 ). In the OMC-2P cells, MDR1 expression levels were $22347.0 \pm 1078.1,20965.8 \pm 1645.4,16987.8 \pm 1833.2$ 


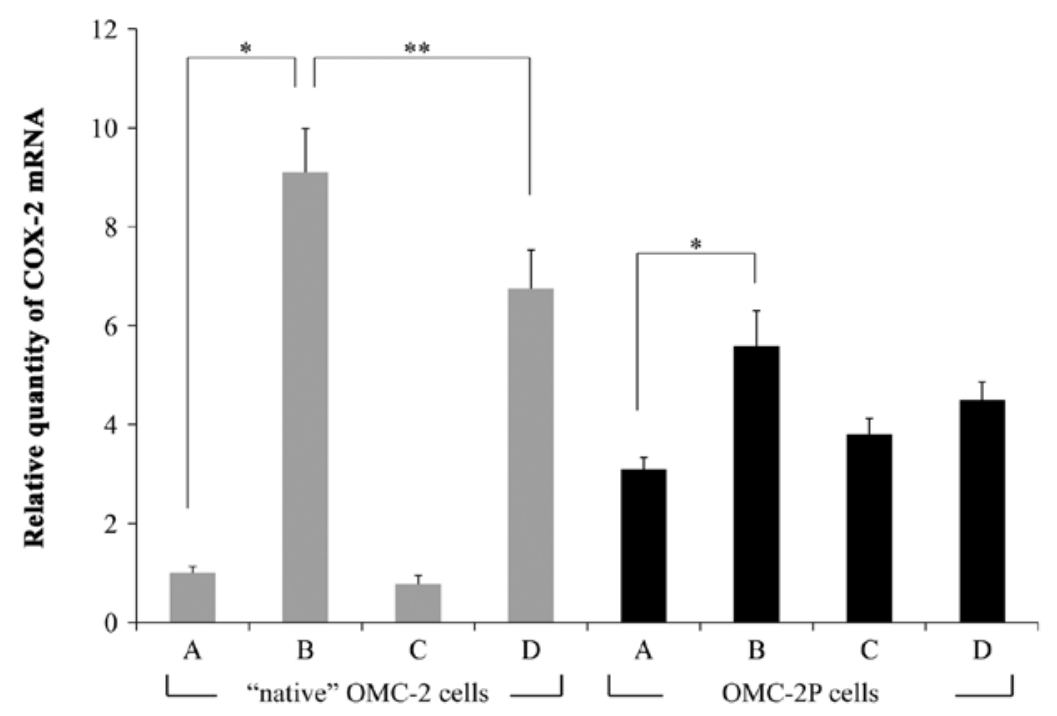

Figure 2. $C O X-2$ mRNA expression in endometrial cancer cell lines. In OMC-2 cells, $C O X-2 \mathrm{mRNA}$ expression was significantly upregulated by paclitaxel treatment $(\mathrm{P}<0.01)$ when compared to that of the untreated control and was downregulated by co-administration with etodolac when compared to that of cells treated with paclitaxel alone $(\mathrm{P}<0.05)$. In the OMC-2P cells, $C O X-2 \mathrm{mRNA}$ expression was also significantly upregulated by paclitaxel treatment $(\mathrm{P}<0.01)$ when compared to that of the control and tended to be downregulated by co-administration with etodolac $(\mathrm{P}=0.067)$. The expression of $C O X-2$ in the control OMC-2P cells was about 3-times higher than that in the control OMC-2 cells. A, untreated control; B, paclitaxel $1 \mu \mathrm{g} / \mathrm{ml}$ for $24 \mathrm{~h} ; \mathrm{C}$, etodolac $10 \mu \mathrm{g} / \mathrm{ml}$ for $24 \mathrm{~h}$; D, paclitaxel $1 \mu \mathrm{g} / \mathrm{ml}$ with etodolac $10 \mu \mathrm{g} / \mathrm{ml}$ for $\left.24 \mathrm{~h} ;{ }^{*} \mathrm{P}<0.01,{ }^{* *} \mathrm{P}<0.05\right)$.
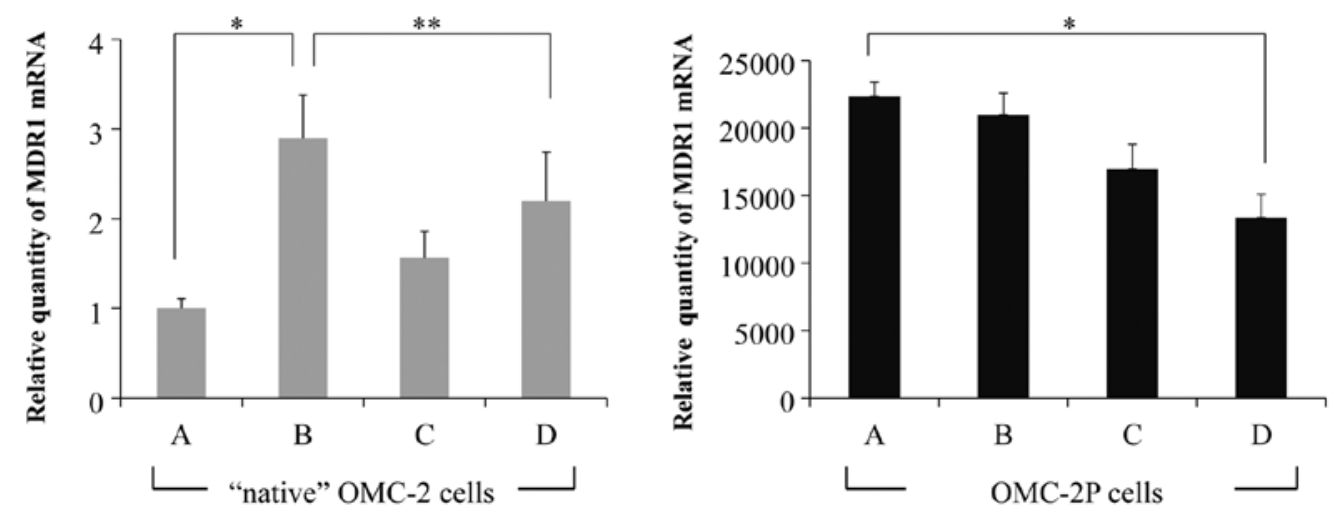

Figure 3. MDR1 mRNA expression in endometrial cancer cell lines. In the OMC-2 cells, MDR1 mRNA expression was significantly upregulated by paclitaxel treatment $(\mathrm{P}<0.01)$ when compared to that of control cells and was downregulated by co-administration of paclitaxel and etodolac compared to that of cells treated with paclitaxel alone $(\mathrm{P}<0.05)$. In the OMC-2P cells, MDR1 mRNA levels in the control OMC-2P cells were markedly higher than levels in the control 'native' OMC-2 cells and was not affected by paclitaxel or etodolac treatment, but was downregulated by co-administration of paclitaxel and etodolac $(\mathrm{P}<0.01)$. A, untreated control; B, paclitaxel $1 \mu \mathrm{g} / \mathrm{ml}$ for $24 \mathrm{~h}$; C, etodolac $10 \mu \mathrm{g} / \mathrm{ml}$ for $24 \mathrm{~h}$; D, paclitaxel $1 \mu \mathrm{g} / \mathrm{ml}$ with etodolac $10 \mu \mathrm{g} / \mathrm{ml}$ for $24 \mathrm{~h}$; ${ }^{*} \mathrm{P}<0.01$, ${ }^{* *} \mathrm{P}<0.05$.

and $13369.8 \pm 1731.5$ in the untreated control, paclitaxel-treated, etodolac-treated, and paclitaxel plus etodolac-treated cells, respectively. MDRl mRNA level in the control OMC-2P cells was markedly higher than that in the control 'native' OMC-2 cells and was not affected by paclitaxel or etodolac treatment, but was downregulated by co-administration of paclitaxel and etodolac $(\mathrm{P}<0.01$; Fig. 3$)$.

$P G E_{2}$ concentrations in the supernatants of $O M C-2$ and $O M C-2 P$ cells. The concentrations of $\mathrm{PGE}_{2}$ in the supernatants of the untreated control, paclitaxel-treated, etodolac-treated and paclitaxel plus etodolac-treated OMC-2 cells were $2.5 \pm 0.6$, $7.9 \pm 0.8,2.2 \pm 0.5$ and $4.1 \pm 0.6 \mathrm{pg} / \mathrm{ml}$, respectively. $\mathrm{PGE}_{2}$ was significantly upregulated by paclitaxel treatment $(\mathrm{P}<0.01)$ when compared to that in the untreated control cells and was downregulated by co-administration of paclitaxel and etodolac compared to that in cells treated with paclitaxel alone $(\mathrm{P}<0.01$; Fig. 4). The concentrations of $\mathrm{PGE}_{2}$ in the supernatants of the untreated control, paclitaxel-treated, etodolac-treated and paclitaxel plus etodolac-treated OMC-2P cells were 3.8 \pm 0.3 , $5.5 \pm 0.8,3.5 \pm 0.3$ and $3.7 \pm 0.4 \mathrm{pg} / \mathrm{ml}$, respectively. $\mathrm{PGE}_{2}$ was also upregulated by paclitaxel treatment $(\mathrm{P}<0.05)$ when compared to that in the untreated control OMC-2P cells and was downregulated by co-administration of paclitaxel and etodolac $(\mathrm{P}<0.05$; Fig. 4$)$.

R123 efflux assay. In the 'native' OMC-2 cells, the percentages of R123 efflux at time 0 (load) were $8.3 \pm 0.2,16.6 \pm 0.5$ and $10.5 \pm 0.5 \%$ in the untreated control, paclitaxel-treated, and paclitaxel plus etodolac-treated cells, respectively. These percentages were increased after $2 \mathrm{~h}$ of efflux to $14.2 \pm 0.4$, $34.4 \pm 1.5$ and $20.6 \pm 1.1 \%$, respectively (Fig. 5). In the OMC-2P 


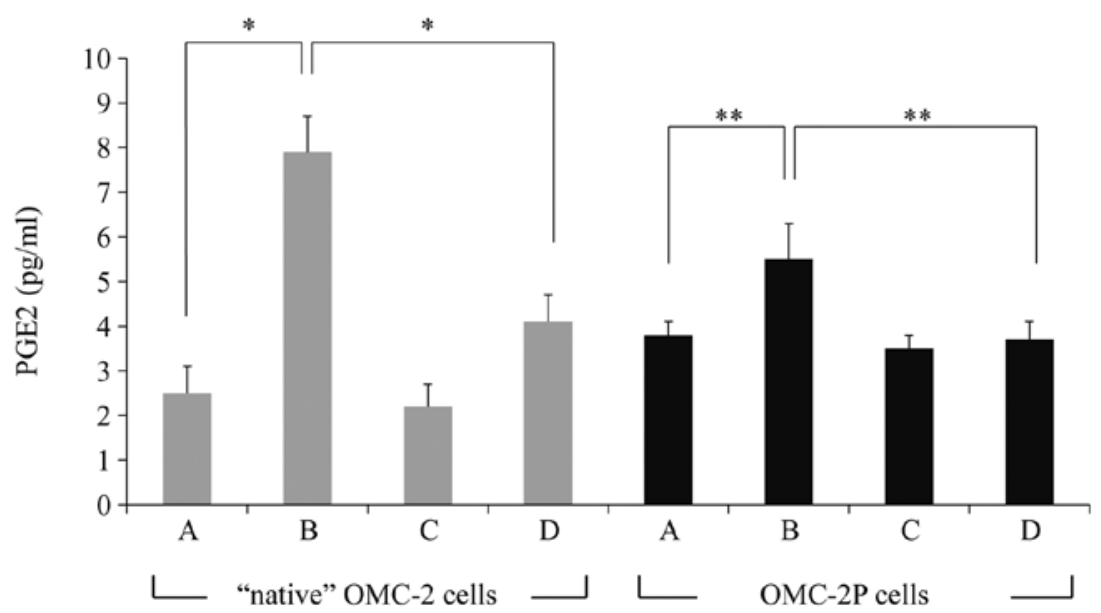

Figure 4. $\mathrm{PGE}_{2}$ concentrations in the supernatants of OMC-2 and OMC-2P cells. In the OMC-2 cells, the concentration of $\mathrm{PGE}_{2}$ was significantly upregulated by paclitaxel treatment $(\mathrm{P}<0.01)$ when compared to the concentration in the control, and was downregulated by co-administration with etodolac when compared to the concentration in the cells treated by paclitaxel alone $(\mathrm{P}<0.01)$. In the $\mathrm{OMC}-2 \mathrm{P}$ cells, the concentration of $\mathrm{PGE}_{2}$ was also upregulated by paclitaxel treatment $(\mathrm{P}<0.05)$ when compared to that in the control, and was downregulated by co-administration with etodolac $(\mathrm{P}<0.05)$. A, untreated control; B, paclitaxel $1 \mu \mathrm{g} / \mathrm{ml}$ for $24 \mathrm{~h}$; C, etodolac $10 \mu \mathrm{g} / \mathrm{ml}$ for $24 \mathrm{~h}$; D, paclitaxel $1 \mu \mathrm{g} / \mathrm{ml}$ with etodolac $10 \mu \mathrm{g} / \mathrm{ml}$ for $24 \mathrm{~h}$; ${ }^{*} \mathrm{P}<0.01,{ }^{* *} \mathrm{P}<0.05$.

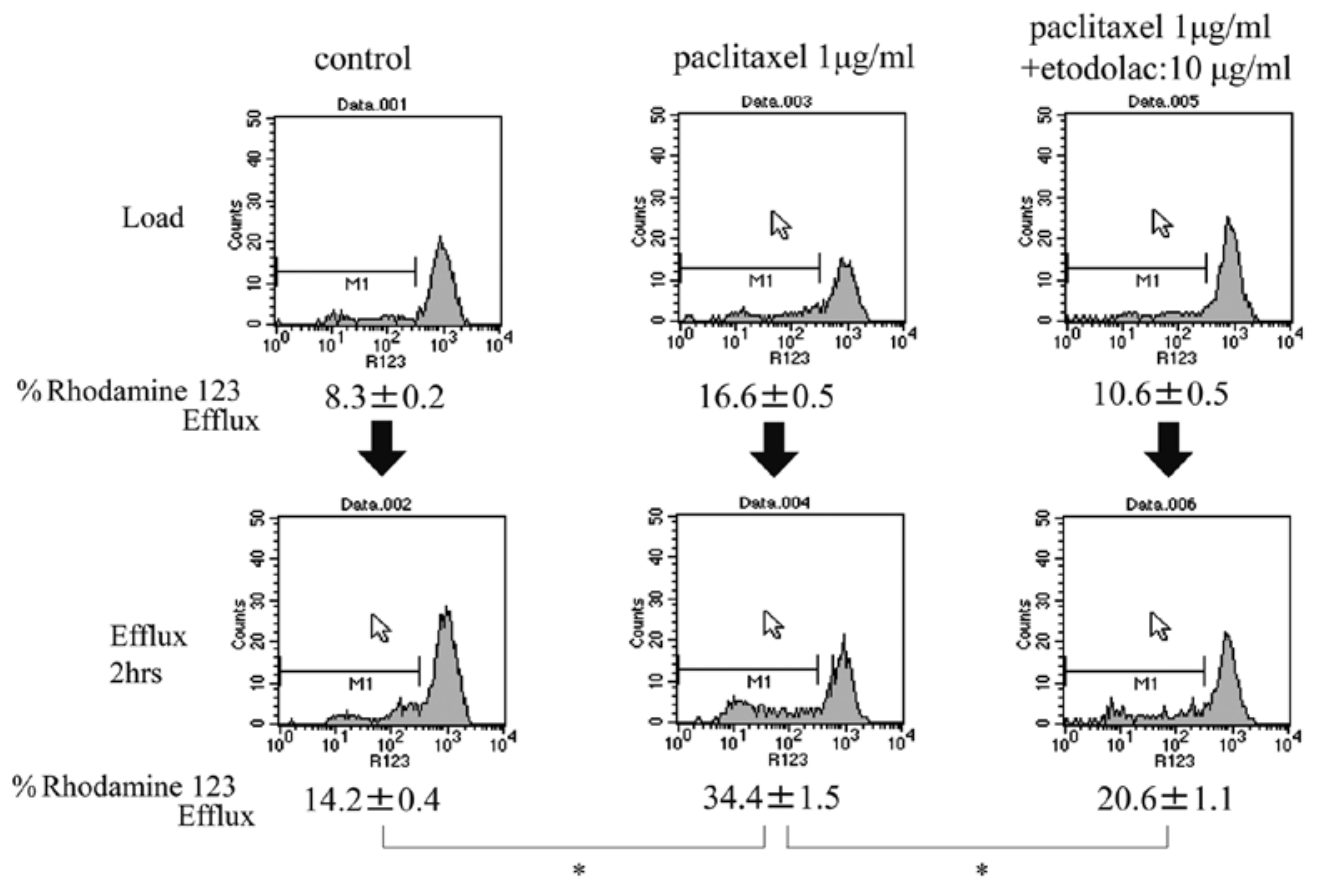

Figure 5. Rhodamine 123 efflux assay in OMC-2 cells. In the OMC-2 cells, the percentages of R123 efflux at load were 8.3 $\pm 0.2,16.6 \pm 0.5$ and $10.5 \pm 0.5 \%$ in the untreated control, paclitaxel-treated, and paclitaxel plus etodolac-treated cells, respectively. These percentages were increased after $2 \mathrm{~h}$ of efflux to $14.2 \pm 0.4$, $34.4 \pm 1.5$ and $20.6 \pm 1.1 \%$, respectively. Intracellular R123 accumulation was decreased by paclitaxel treatment and increased by co-administration of paclitaxel and etodolac in the OMC-2 cells. $\mathrm{x}$-axis, fluorescence intensity; $\mathrm{y}$-axis, cell number. ${ }^{*} \mathrm{P}<0.01$.

cells, the percentages of R123 efflux at load were $0.3 \pm 0.2$, $5.6 \pm 0.6$ and $4.9 \pm 0.9 \%$ in the untreated control, paclitaxeltreated, and paclitaxel plus etodolac-treated cells, respectively. These percentages were markedly increased after $2 \mathrm{~h}$ of efflux to $57.1 \pm 2.0,93.5 \pm 1.9$ and $73.6 \pm 3.3 \%$, respectively (Fig. 6). Intracellular accumulation of R123 after $2 \mathrm{~h}$ of efflux was dramatically decreased in the OMC-2P cells when compared to that in OMC-2 cells, and R123 accumulation was decreased by paclitaxel treatment and increased by co-administration of paclitaxel and etodolac in both the OMC-2P and OMC-2 cells.
Concentrations of intracellular paclitaxel. The concentrations of intracellular paclitaxel were $20.5 \pm 2.2$ and $47.2 \pm 3.8$ (ng/g wet weight $/ 10^{4}$ cells) in the 'native' OMC-2 cells treated with paclitaxel or co-administration of paclitaxel and etodolac, respectively. The concentration of intracellular paclitaxel in the OMC-2 cells treated with both paclitaxel and etodolac was significantly higher than that in cells treated with paclitaxel alone $(\mathrm{P}<0.01)$. In the OMC-2P cells, the concentrations of intracellular paclitaxel were $2.3 \pm 0.8$ and $9.2 \pm 1.3$ (ng/g wet weight $/ 10^{4}$ cells) in cells treated with paclitaxel or 


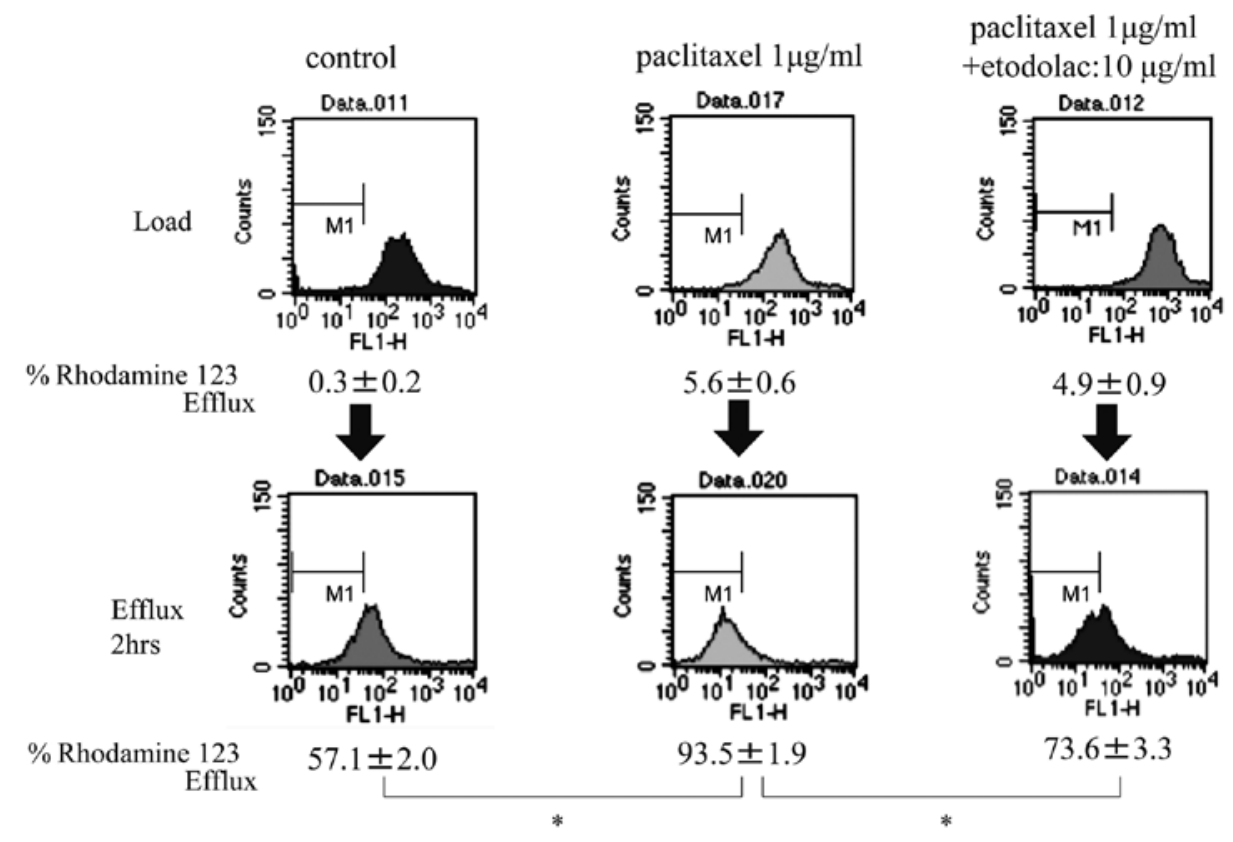

Figure 6. Rhodamine 123 efflux assay in OMC-2P cells. In the OMC-2P cells, the percentages of R123 efflux at load were $0.3 \pm 0.2,5.6 \pm 0.6$ and $4.9 \pm 0.9 \%$ in the untreated control, paclitaxel-treated, and paclitaxel plus etodolac-treated cells, respectively. These percentages were markedly increased after $2 \mathrm{~h}$ of efflux to $57.1 \pm 2.0,93.5 \pm 1.9$ and $73.6 \pm 3.3 \%$, respectively. Intracellular accumulation of R123 after $2 \mathrm{~h}$ of efflux was dramatically decreased in the OMC-2P cells when compared to that in the OMC-2 cells, and R123 accumulation was decreased by paclitaxel treatment and increased by co-administration of paclitaxel and etodolac in the OMC-2P cells. $\mathrm{x}$-axis, fluorescence intensity; $\mathrm{y}$-axis, cell number. ${ }^{*} \mathrm{P}<0.01$.

Table I. Concentration of intracellular paclitaxel in the OMC-2 and OMC-2P cells.

Intracellular paclitaxel concentration

Cell lines Treatment $\quad\left(\mathrm{ng} / \mathrm{g}\right.$ wet weight $/ 10^{4}$ cells $)$

\begin{tabular}{ccc}
\hline OMC-2 & Paclitaxel $1 \mu \mathrm{g} / \mathrm{ml}$ & $20.5 \pm 2.2$ \\
& Paclitaxel $1 \mu \mathrm{g} / \mathrm{ml}$ & $47.2 \pm 3.8^{\mathrm{a}}$ \\
& + etodolac $10 \mu \mathrm{g} / \mathrm{ml}$ & \\
OMC-2P & Paclitaxel $1 \mu \mathrm{g} / \mathrm{ml}$ & $2.3 \pm 0.8^{\mathrm{b}}$ \\
& Paclitaxel $1 \mu \mathrm{g} / \mathrm{ml}$ & $9.2 \pm 1.3^{\mathrm{c}}$ \\
& + etodolac $10 \mu \mathrm{g} / \mathrm{ml}$ &
\end{tabular}

${ }^{\mathrm{a}} \mathrm{P}<0.01$, significantly increased when compared with OMC-2 cells treated with paclitaxel alone; ${ }^{b} \mathrm{P}<0.01$, significantly lower when compared with OMC-2 cells treated with paclitaxel alone. ${ }^{\mathrm{P}} \mathrm{P}<0.01$, significantly increased when compared with OMC-2P cells treated with paclitaxel alone.

co-administration of paclitaxel and etodolac, respectively. The concentration of intracellular paclitaxel in the OMC-2P cells treated with paclitaxel was significant lower than that in the OMC- 2 cells treated with paclitaxel alone $(\mathrm{P}<0.01)$ and was significantly increased after co-administration of paclitaxel and etodolac $(\mathrm{P}<0.01$; Table I).

\section{Discussion}

COX-2 has been shown to modulate MDR1 expression, and inhibition of COX-2 activity results in downregulation of
MDR1 expression and function in various types of cancer cells $(12-15,19,20)$. Moreover, several studies have demonstrated that cytotoxic drug-induced MDR1 overexpression is effectively downregulated by COX-2 inhibitors in vitro $(16,26,27)$. Chen et al (27)reported that the expression and function of MDR1 in the breast cancer cell line MCF-7 is upregulated by treatment with doxorubicin, indicating the chemoresistant phenotype, and its expression and function are also significantly downregulated by treatment with both doxorubicin and the COX-2 inhibitor celecoxib. They concluded that celecoxib is capable of preventing the development of the chemoresistant phenotype induced by doxorubicin. Zatelli et al (16) also demonstrated that treatment with a selective COX-2 inhibitor (NS-398) significantly reduced MDR1 expression in doxorubicin-resistant breast cancer cells (rMCF7 cells), and they hypothesized that COX-2 inhibitors can prevent or reduce the development of the chemoresistant phenotype in breast cancer cells by inhibiting MDR1 expression and function.

In the present study we demonstrated, for the first time, the positive relationship between $C O X-2$ and MDRI mRNA expression in endometrial cancers. We established a paclitaxelresistant cell line, designated OMC-2P, from 'native' OMC-2 cells. $C O X-2$ mRNA expression and $\mathrm{PGE}_{2}$ production were elevated in the 'resistant' OMC-2P cells when compared to these values in the OMC-2 cells. Moreover, MDRI mRNA expression was markedly upregulated in the OMC-2P cells. In the OMC-2 cells, COX-2 and MDR1 mRNAs were significantly upregulated by paclitaxel treatment and downregulated by co-administration with etodolac. In the OMC-2P cells, COX-2 mRNA expression was also significantly upregulated by paclitaxel treatment and tended to be downregulated by co-administration with etodolac. Moreover, the markedly elevated MDRI mRNA expression levels in OMC-2P cells 
were not further influenced by treatment with paclitaxel or etodolac alone, but were downregulated by co-administration of paclitaxel and etodolac. Intracellular accumulation of R123 as determined by flow cytometry was markedly decreased in the OMC-2P cells when compared to that in the OMC-2 cells, but was decreased by paclitaxel treatment and increased by co-administration of paclitaxel plus etodolac in both cell lines. The actual concentration of intracellular paclitaxel in the OMC-2P cells as measured by HPLC was significantly lower than that in the OMC-2 cells when treated with paclitaxel alone, but was significantly increased after co-administration of paclitaxel and etodolac. In summary, our data suggest the possible downregulation of $M D R 1$ by the COX-2 inhibitor etodolac, which may enhance the accumulation of MDR1 substrates, such as paclitaxel.

Several mechanisms have been proposed to explain the close association between $C O X-2$ and $M D R 1$ expression and the downregulation of MDR1 by COX-2 inhibitors. The $M D R 1$ gene promoter contains putative binding sites for the transcription factors activator protein 1 (AP-1) and nuclear factor- $\kappa \mathrm{B}(\mathrm{NF}-\kappa \mathrm{B})$, which appear to be relevant for MDRI gene induction (28). Drug resistance in breast cancer MCF-7 cells has been reported to be accompanied by increases in AP-1 activity (29). Moreover, NF- $\kappa \mathrm{B}$, a ubiquitous transcription factor involved in immunity, inflammation, regulation of cell growth, differentiation, and apoptosis, was found to induce drug resistance through MDR1 expression $(28,30)$. The inhibition of these factors by COX-2 inhibitors would induce negative regulation of the $M D R l$ gene. Ratnasinghe et al (12) postulated that prostaglandins modulate the $M D R 1$ gene via the induction of phosphokinase $\mathrm{C}$ (PKC) and subsequent expression of c-Jun (a subunit of AP-1). COX-2 inhibitors could block this cascade, resulting in negative modulation of the MDRl gene. Chen et al (27) showed that the COX-2 inhibitor celecoxib decreased $\mathrm{c}-\mathrm{Jun}$ and NF- $\mathrm{B}$ expression at the mRNA and protein level and significantly impaired the DNA-binding activity of AP-1 and NF- $\kappa$ B, which was partly associated with downregulated MDR1 expression induced by doxorubicin. Moreover, the activity of c-Jun $\mathrm{NH}_{2}$-terminal kinase (JNK), a member of the mitogen-activated protein kinase family that functions downstream of COX-2, has been implicated in the regulation of MDR1 expression, and COX-2 and JNK signaling pathways are associated with MDR1mediated drug resistance $(31,32)$.

From the above findings, we assumed that cellular stress caused by paclitaxel treatment induced COX-2 expression and $\mathrm{PGE}_{2}$ production in the present study, which in turn may have enhanced the expression of transcription factors, such as AP-1 or NF- $\kappa \mathrm{B}$, and thus ultimately induced the expression of MDR1 in endometrial cancer cells as well as in other types of cancer cells. Therefore, our data suggest that the COX-2 inhibitor suppressed these mediators and paclitaxel efflux, thereby increasing paclitaxel concentrations in the cells.

Although AP-1 and $\mathrm{NF}-\kappa \mathrm{B}$ have been shown to enhance the effects of COX-2 inhibitors on cytotoxic drugs, several studies have shown conflicting results. Moreover, our data did not exclude the possibility that other transcription factors, such as Sp1, nuclear transcription factor Y (NF-Y), Y box binding protein 1 (YB-1), p53, and CCAAT/enhancer binding protein $\beta(\mathrm{C} / \mathrm{EBP} \beta)$, may be involved in mediating the down- regulation of MDR1 expression by COX-2 inhibitors. It is also possible that transcription factors may interact with each other. Therefore, the precise mechanisms through which COX-2 inhibitors enhance the efficacy of cytostatic drugs are not fully understood.

In endometrial cancers, chemotherapy is indicated for patients with advanced or recurrent disease, and platinumbased regimens in combination with doxorubicin or taxanes have been recommended in treatment guidelines. However, outcomes for patients with advanced-stage or recurrent disease are poor and such cancers are rarely curable. In particular, the prognosis for patients with recurrent disease showing multiple-drug resistance is markedly poor. Therefore, it is critical to overcome resistance to cytotoxic drugs in order to improve the prognoses of these patients. In the present study, we demonstrated, for the first time, the possibility of modulating or overcoming paclitaxel resistance by $\mathrm{COX}-2$ inhibitors in endometrial cancers.

In conclusion, the findings of the present study suggest that paclitaxel resistance in endometrial cancers may be associated with elevated COX-2 and MDR1 expression in cancer cells. It is possible that co-administration of paclitaxel and COX-2 inhibitors may play a key role in modulating or overcoming paclitaxel resistance in endometrial cancers.

\section{References}

1. Dannenberg AJ and Subbaramaiah K: Targeting cyclooxygenase-2 in human neoplasia: rationale and promise. Cancer Cell 4: 431-436, 2003

2. Hasegawa K, Ohashi Y, Ishikawa K, et al: Expression of cyclooxygenase-2 in uterine endometrial cancer and anti-tumor effects of a selective COX-2 inhibitor. Int J Oncol 26: 1419-1428, 2005.

3. Genç S, Attar E, Gürdöl F, Kendigelen S, Bilir A and Serdaroğlu H: The effect of COX-2 inhibitor, nimesulide, on angiogenetic factors in primary endometrial carcinoma cell culture. Clin Exp Med 7: 6-10, 2007.

4. Wood NJ, Quinton NA, Burdall S, Sheridan E and Duffy SR: Exploring the potential chemopreventative effect of aspirin and rofecoxib on hereditary nonpolyposis colorectal cancer-like endometrial cancer cells in vitro through mechanisms involving apoptosis, the cell cycle, and mismatch repair gene expression. Int J Gynecol Cancer 17: 447-454, 2007.

5. Sooriakumaran P, Coley HM, Fox SB, Macanas-Pirard P, Lovell DP, Henderson A, et al: A randomized controlled trial investigating the effects of celecoxib in patients with localized prostate cancer. Anticancer Res 29: 1483-1488, 2009.

6. Hasegawa K, Torii Y, Ishii R, Oe S, Kato R and Udagawa Y: Effects of a selective COX-2 inhibitor in patients with uterine endometrial cancers. Arch Gynecol Obstet 284: 1515-1521, 2011.

7. Soriano AF, Helfrich B, Chan DC, et al: Synergistic effects of new chemopreventive agents and conventional cytotoxic agents against human lung cancer cell lines. Cancer Res 59: 6178-6184, 1999.

8. Hida T, Kozaki K, Ito H, et al: Significant growth inhibition of human lung cancer cells both in vitro and in vivo by the combined use of a selective cyclooxygenase 2 inhibitor, JTE-522, and conventional anticancer agents. Clin Cancer Res 8: 2443-2447, 2002.

9. Altorki NK, Keresztes JL, Port JL, Libby DM, Korst RJ, Flieder DB, et al: Celecoxib, a selective cyclo-oxygenase-2 inhibitor, enhances the response to preoperative paclitaxel and carboplatin in early-stage non-small-cell lung cancer. J Clin Oncol 21: 2645-2650, 2003.

10. Lipton A, Campbell-Baird C, Witters L, Harvey H and Ali S: Phase II trial of gemcitabine, irinotecan, and celecoxib in patients with advanced pancreatic cancer. J Clin Gastroenterol 44: 286-288, 2010.

11. Aruajo AM, Mendez JC, Coelho AL, Sousa B, Barata F, Figueiredo A, et al: Phase II study of celecoxib with cisplatin plus etoposide in extensive-stage small cell lung cancer. Cancer Invest 27: 391-396, 2009. 
12. Ratnasinghe D, Daschner PJ, Anver MR, et al: Cyclooxygenase-2, P-glycoprotein-170 and drug resistance: Is chemoprevention against multidrug resistance possible? Anticancer Res 21: 2141-2147, 2001.

13. Patel VA, Dunn MJ and Sorokin A: Regulation of MDR-1 (p-glycoprotein) by cyclooxygenase-2. J Biol Chem 277: 38915-38920, 2002.

14. Sorokin A: Cyclooxygenase-2: potential role in regulation of drug efflux and multidrug resistance phenotype. Curr Pharm Des 10: 647-657, 2004

15. Zatelli MC, Luchin A, Piccin D, et al: Cyclooxgenase-2 inhibitors reverse chemoresistance phenotype in medullary thyroid carcinoma by a permeability glycoprotein-mediated mechanism. J Clin Endocrinol Metab 90: 5754-5760, 2005.

16. Zatelli MC, Luchin A, Tagliati F, et al: Cyclooxygenase-2 inhibitors prevent the development of chemoresistance phenotype in a breast cancer cell line by inhibiting glycoprotein p-170 expression. Endocr Relat Cancer 14: 1029-1038, 2007.

17. Fontaine M,Elmquist WF and Miller DW: Use of rhodamine 123 to examine the functional activity of P-glycoprotein in primary cultured brain microvessel endothelial cell monolayers. Life Sci 59: 1521-1531, 1996.

18. Hille S, Rein DT, Riffelmann M, et al: Anticancer drugs induce mdr1 gene expression in recurrent ovarian cancer. Anticancer Drugs 17: 1041-1044, 2006.

19. Zrieki A, Farinotti R and Buyse M: Cyclooxygenase inhibitors down regulate P-glycoprotein in human colorectal Caco-2 cell line. Pharm Res 25: 1991-2001, 2008.

20. Fantappiè O, Masini E, Sardi I, et al: The MDR phenotype is associated with the expression of COX-2 and iNOS in a human hepatocellular carcinoma cell line. Hepatology 35: 843-852, 2002.

21. Raspollini MR, Amunni G, Villanucci A, Boddi V and Taddei GL: Increased cyclooxygenase-2 (COX-2) and P-glycoprotein-170 (MDR1) expression is associated with chemotherapy resistance and poor prognosis. Analysis in ovarian carcinoma patients with low and high survival. Int J Gynecol Cancer 15: 255-260, 2005.

22. Surowiak P, Materna V, Denkert C, et al: Significance of cyclooxygenase 2 and MDR1/P-glycoprotein coexpression in ovarian cancers. Cancer Lett 235: 272-280, 2006.
23. Xi H, Baldus SE, Warnecke-Eberz U, et al: High cyclooxygenase-2 expression following neoadjuvant radiochemotherapy is associated with minor histopathologic response and poor prognosis in esophageal cancer. Clin Cancer Res 11: 8341-8347, 2005.

24. Saikawa Y, Sugiura T, Toriumi F, et al: Cyclooxygenase-2 gene induction causes CDDP resistance in colon cancer cell line, HCT-15. Anticancer Res 24: 2723-2728, 2004.

25. Yamada T, Ueda M, Maeda T, et al: Establishment and characterization of CA125 producing cell line (OMC-2) originating from a human endometrial adenocarcinoma. Asia Oceania J Obstet Gynecol 15: 403-416, 1989.

26. Puhlmann U, Ziemann C, Ruedell G, et al: Impact of the cyclooxygenase system on doxorubicin-induced functional multidrug resistance 1 overexpression and doxorubicin sensitivity in acute myeloid leukemic HL-60 cells. J Pharmacol Exp Ther 312: 346-354, 2005

27. Chen C, Shen HL, Yang J, Chen QY and Xu WL: Preventing chemoresistance of human breast cancer cell line, MCF-7 with celecoxib. J Cancer Res Clin Oncol 137: 9-17, 2011.

28. Bentires-Alj M, Barbu V, Fillet M, et al: NF- $\kappa \mathrm{B}$ transcription factor induces drug resistance through MDR1 expression in cancer cells. Oncogene 22: 90-97, 2003.

29. Daschner PJ, Ciolino HP, Plouzek CA and Yeh GC: Increased AP-1 activity in drug resistant human breast cancer MCF-7 cells. Breast Cancer Res Treat 53: 229-240, 1999.

30. van Wijngaarden J, van Beek E, van Rossum G, et al: Celecoxib enhances doxorubicin-induced cytotoxicity in MDA-MB231 cells by NF- $\kappa \mathrm{B}$-mediated increase of intracellular doxorubicin accumulation. Eur J Cancer 43: 433-442, 2007.

31. Bassiouny AR, Zaky A and Neenaa HM: Synergistic effect of celecoxib on 5-fluorouracil-induced apoptosis in hepatocellular carcinoma patients. Ann Hepatol 9: 410-418, 2010.

32. Sui H,Zhou S, Wang Y, et al: COX-2 contributes to P-glycoproteinmediated multidrug resistance via phosphorylation of c-Jun at Ser63/73 in colorectal cancer. Carcinogenesis 32: 667-675, 2011. 